$10-28-2015$

\title{
Cloudy with a Chance of Sunshine, or the Future of Magazine Publishing
}

George K. Thiruvathukal

Loyola University Chicago, gkt@cs.luc.edu

Follow this and additional works at: https://ecommons.luc.edu/cs_facpubs

Part of the Computer Sciences Commons

\section{Recommended Citation}

G. K. Thiruvathukal, "Cloudy with a Chance of Sunshine, or the Future of Magazine Publishing," in Computing in Science \& Engineering, vol. 17, no. 6, pp. 4-5, Nov.-Dec. 2015. doi: 10.1109/MCSE.2015.119

This Article is brought to you for free and open access by the Faculty Publications and Other Works by Department at Loyola eCommons. It has been accepted for inclusion in Computer Science: Faculty Publications and Other Works by an authorized administrator of Loyola eCommons. For more information, please contact ecommons@luc.edu.

\section{c) (†) $\ominus$}

This work is licensed under a Creative Commons Attribution-Noncommercial-No Derivative Works 3.0 License. Copyright @ 2015 George K. Thiruvathukal 


\section{FROM THE EDITORS}

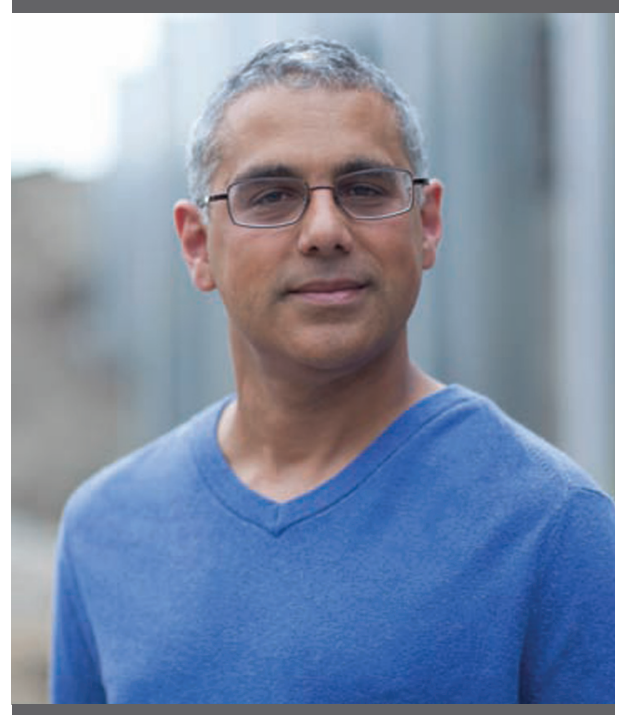

by George K. Thiruvathukal Loyola University Chicago

\section{Cloudy with a Chance of Sunshine, or the Future of Magazine Publishing}

n 2011, my colleagues David Dennis, Konstantin Läufer, and I wrote an article about our initial experience to move several university IT-related functions to the cloud and other more socially focused technologies (http://ecommons.luc.edu/ cs_facpubs/36/). Our article wasn't intended to be prescriptive_-as in "you should do this, too"-it focused on the realities facing academic departments in universities, realities that also affect professional societies and publications such as ours. It was a realization that the vision of Sun Microsystems (creators of Java and the notion of "the network is the computer" as coined by John Gage) was finally springing to life, albeit mostly without Sun's involvement.

\section{The Road Ahead}

As we close 2015 here at CiSE, it's becoming abundantly clear-at least to this EICthat this is the year where cloud computing entered a new phase of maturity. Cloud computing has taken the world by storm (pardon the pun), and the outlook is sunny, despite the canopy that springs to mind when thinking of clouds. Editorially speaking, we've already covered cloud computing and related topics (such as extreme data) in the past year. My tenure as EIC will end in 2016 with special issues on science in the cloud and transparent computing.

But I want to speak to some recent developments that I think will have a great impact on the future of academic publishing. In a lot of ways, this amounts to a profound hope that my publishing house (that being the IEEE Computer Society) and others will take notice of the world around them and adapt to a new generation of authors. We need to use these technologies to create our publications at the Computer Society-and soon.

As many of you already know, our magazine (and others in the family) accepts submissions in various formats (Word, plaintext, PostScript, and PDF files; www. computer.org/web/peer-review/magazines), the operative word here being flles. The notion of a file, especially when it comes to writing, is increasingly a late 20th century relic. I'll return to this thought in a moment, but when you submit your article, it inevitably ends up in a Word document. While there are some affordances associated with Microsoft Word, it's less than ideal and should be abstracted away by the cloud. There's no shortage of rock-solid collaboration tools (such as Google Docs), and even Microsoft offers a cloudbased version of Word with Office 365, which is seemingly improving by the minute. (I use online Excel to fill in spreadsheets with macros, such as the ones for expense reports.)

Google Docs is a tantalizing alternative: it has 90 to 95 percent fewer features than Microsoft Word, which has the ultimate effect of improving your own productivity as an author (this article was produced in Google Docs). It offers a rich but straightforward editor, where the primary focus is on writing as opposed to sophisticated formatting and layout. More importantly, it offers support for different roles (author-viewer-editor). When authors submit to CiSE, their document usually ends up in Word, and one of our beloved staff editors (okay, her name is Jenny, and she edited this for me via The Google) then formats, marks up, and sends the file back to the authors for review. The authors then make their changes and send the Word document back, editors review the changes, and the "clean" file goes out for copy layout and final production. The entire process is one that works, but it has a significant amount of back and forth, and-in a computer science/software 
engineering sense-is replete with opportunities for error. Worse, it's time-consuming and doesn't make good use of computing, a key principle of which is to automate tedious work. (Tedium wasn't even fun in the 1980s, when I discovered computing and wrote software to score track and field meets on my TRS-80.) More importantly, this automation should lead to greater efficiencies, especially from a cost perspective.

In sum, I contend that authors should no longer submit files, and we should-at a minimum-accept Google and other cloud-based submissions to show that we're hip. Authors should share documents-hosted in the cloud-that can then proceed through a proper editorial workflow, all of which can be handled by the present implementation of Google Drive. Everything from anonymous peer review to copy editing can be done using cloud-based tools, and it can be done with full change tracking (just like Microsoft Word has). Perhaps most important of all: the work for an issue can be organized into proper folder structures and shared with the people who need to see it (the EIC, the editor, and the original author) through to production.

\section{Silver Linings}

Why else is it important to look to the cloud? At the risk of bluntness, we can't afford not to. Our readers are already keenly aware of the cost of print, having seen a wide range of pricing, from $\$ 149$ (which discouraged many of you) to $\$ 69$ (which hopefully brought some of you back). Even the most casual observer (the ones from your physics and math textbooks) can sense that something is wrong when these prices are way beyond what other great magazines (such as The New Yorker) cost. But the writing's on the wall: print (and shipping, especially to our beloved international readers) is an expensive proposition, and one that most professional societies increasingly can't afford to do. The incredible irony is that print and shipping aren't the only terms in the publishing equation: it's the editing, the layout, not to mention the time authors actually put into their submissions. Without the diligent work of our editors and authors, we have nothing to offer our readers.

So what's behind the (high) print cost? Inquiring minds want to know, and I'm making significant progress in figuring it out. My test case is another real-life cloud development, in which my colleague Andy Harrington and I have been working to self-publish our open source book (http://books.cs.luc.edu/introcs-csharp). We wrote the book using only open source tools (the Python Sphinx project), and it's backed by GitHub (a cloud-based open source hosting service). As I write this, we're in the process of releasing a print version of the book (roughly 500 pages) using Amazon's CreateSpace. So how much does it cost to print this little wonder on demand? I ordered a proof copy for about $\$ 10$. (Yes, you read that right: $\$ 10$, plus a nominal shipping cost, with the ability to ship to all regions where Amazon does business!) We're planning to price the book for students, factoring in a small profit that we'll use to support open source projects like Sphinx. So why is it so expensive to do on-demand printing when there are so many awesome cloud-based solutions today? It's obviously not the actual printing, right?

$\mathrm{f}$ course, a magazine is a special animal and probably costs a bit more to print than a one-off book, but much of that cost depends on the choices you make, even when it comes to color printing. In theory, we can get to a price point that's appropriate for our readership and maintains a high-quality print standard. But I think the time is now for us - and other academic/research-focused magazines - to rethink the overall model and understand where we can leverage efficiencies. This includes everything from handling submissions to editing to layout to final realization (print and other e-savvy formats). The only promising way to be more efficient is the cloud.

The network is the computer, indeed. 